\title{
Cytotoxic, antioxidative, genotoxic and antigenotoxic effects of Horchata, beverage of South Ecuador
}

\author{
Natalia Bailon-Moscoso ${ }^{1 *}$ (D) Fani Tinitana ${ }^{2}$, Ruth Martínez-Espinosa ${ }^{3}$, Andrea Jaramillo-Velez ${ }^{1}$ \\ Alejandra Palacio-Arpi ${ }^{1}$, Jessica Aguilar-Hernandez ${ }^{1}$ and Juan Carlos Romero-Benavides ${ }^{3}$
}

\begin{abstract}
Background: "Horchata" is an herbal mixture infusion consumed in Southern Ecuador; 66\% of its plants are antiinflammatory medicinal plant, and $51 \%$ are analgesics. Anti-inflammatory substances can prevent carcinogenesis mediated by cytotoxic effects and can prevent DNA damage. The aim of this study was to evaluate the cytotoxicity and apoptotic/antigenotoxic effects of horchata as well as its mechanism.

Methods: Nine different varieties of horchata were prepared in the traditional way and then freeze-dried. Phytochemical screening tested for the presence of secondary metabolites using standard procedures and antioxidant activities. The cytotoxic activity was evaluated on cerebral astrocytoma (D-384), prostate cancer (PC-3), breast cancer (MCF-7), colon cancer (RKO), lung cancer (A-549), immortalized Chinese hamster ovary cells (CHO-K1), and human peripheral blood lymphocytes via a MTS assay. The pro-apoptotic effects were evaluated with Anexin V/Propidium lodide and western blot of Bax, BCl-2, TP53, and TP73. Induction and reduction of ROS were assessed by fluorimetry. Genotoxic and antigenotoxic effects were evaluated with a comet assay and micronuclei on binucleated cells.

Results: Five of nine horchatas had cytotoxic effects against D-384 while not affecting normal cells. These horchatas induce cell death by apoptosis modulated by p53/p73. In CHO-K1 cells, the horchatas decrease the damage induced by hydrogen peroxide and Mitomycin $\mathrm{C}$ measured in the comet and micronucleus assay respectively.
\end{abstract}

Conclusions: The $\mathrm{IC}_{50}$ range of effective horchatas in D-384 was 41 to $122 \mu \mathrm{g} \cdot \mathrm{mL}^{-1}$. This effect may be related to its use in traditional medicine (brain tonic). On the other hand, immortalized Chinese hamster ovary cells (CHO-K1) and lymphocytes did not show a cytotoxic effect. The most potent horchata induced apoptosis via a p53/p73mediated mechanism.

The horchatas present antigenotoxic properties, which may be related to the antioxidant capacity. Future studies on horchata components are necessary to understand the interactions and beneficial properties.

Keywords: Horchata, Cancer, Antigenotoxicity, Anticlastogenic, Apoptosis

\footnotetext{
* Correspondence: ncbailon@utpl.edu.ec

${ }^{1}$ Departamento de Ciencias de la Salud, Universidad Técnica Particular de

Loja, Loja, Ecuador

Full list of author information is available at the end of the article
} International License (http://creativecommons.org/licenses/by/4.0/, which permits unrestricted use, distribution, and reproduction in any medium, provided you give appropriate credit to the original author(s) and the source, provide a link to the Creative Commons license, and indicate if changes were made. The Creative Commons Public Domain Dedication waiver (http://creativecommons.org/publicdomain/zero/1.0/) applies to the data made available in this article, unless otherwise stated. 


\section{Background}

The low incidence of chronic non-communicable diseases such as cardiovascular diseases, metabolic disorders, and lower risk of a variety of cancers is associated with frequent consumption of plant-derived foods such as vegetables, fruits, tea, and herbs [1]. "Horchata" $(\mathrm{HRCH})$ is a heritage drink in Southern Ecuador and is consumed for its therapeutic uses. HRCH is also called "aguas frescas" or "agua de frescos" and is an herbal mixture infusion of 16 to 32 medicinal plants depending on their spatial and temporal availability. The species to prepare $\mathrm{HRCH}$ are generally traded in a group locally named as "atado", "manojo", "ramillete" or "tongo" that is boiled for $10 \mathrm{~min}$ and can be consumed cold or hot [2].

$\mathrm{HRCH}$ is very popular in in Southern Ecuador particularly among the indigenous people who believe that the therapeutic effect of the drink is improved when plants locally known as "calientes" (warm) and "frías" (cold) are properly combined. The urban and rural people who consume horchata in Loja province report positive benefits.

Previous studies have shown that some culturally important plant species can treat circulatory, digestive, nervous, and respiratory disease; $66 \%$ of medicinal plant species are anti-inflammatory, and 51\% are analgesics [2]. These activities are related to protective effects because these chronic inflammation processes are related to carcinogenesis [3-8], while anti-inflammatory substances contribute to chemoprevention [9-14]. Cancer chemoprevention includes long-term administration of pharmacological or natural compounds to prevent or slow down the cancer development [15-19]. Antigenotoxic agents exhibit desirable chemotherapeutic effects and control cancer.

Studies of cytotoxicity and genotoxicity/antigenotoxicity are rapid methods to assess the innocuousness and possible beneficial effects of single compounds or complex mixtures and foods $[20,21,33,34]$. The aim of this study is to evaluate the protective effects of this drink in southern Ecuador. We studied the cytotoxic capacity in tumor cells as a protector of DNA damage using genotoxic agents that follow different DNA damaging pathways including oxidation and alkylation.

\section{Methods}

\section{Materials}

The following reagents and chemicals were purchased from Sigma-Aldrich, St. Louis, USA: 2' -7' -dichlorofluorescin diacetate $\left(\mathrm{H}_{2} \mathrm{DCFDA}\right)$, balanced salt solution (HBSS), sodium hydroxide $(\mathrm{NaOH})$, potassium chloride $(\mathrm{KCl})$, sodium bicarbonate $\left(\mathrm{NaHCO}_{3}\right)$, sodium phosphate dibasic anhydrous $\left(\mathrm{NaHPO}_{4}\right)$, monobasic potassium phosphate $\left(\mathrm{KH}_{2} \mathrm{PO}_{4}\right)$, disodium ethylenediaminetetraacetate dihydrate $\left(\mathrm{Na}_{2} \mathrm{EDTA}\right)$, dimethyl sulfoxide (DMSO), sodium chloride $(\mathrm{NaCl})$, methanol, ethanol, peroxidemitomycin $\mathrm{C}$, doxurrubicin, $( \pm)-6$ hydroxy-2,5,7,8 tetra-methylchromane- 2-carboxylic acid (Trolox), 2 diphenyl-1-picrylhydrazyl (DPPH), 2,4,6, tris(2-pyridyl)-s triazine for spectrophometric determination (of $\mathrm{Fe}$ ) (TPTZ), iron III chloride hexahydrate, gallic acid, Folin-Ciocalteu's reagent, and cytochalasin B. The Tris and UltraPure Agarose were purchased from Invitrogen, Carlsbad, California, USA. Roswell Park Memorial Institute (RPMI) 1640 medium, HAMF12, fetal bovine serum (FBS), L-glutamine, antibioticantimycotic (100 units $\cdot \mathrm{mL}^{-1}$ penicillin G, $100 \mu \mathrm{g} \cdot \mathrm{mL}^{-1}$ streptomycin and $0.25 \mu \mathrm{g} \cdot \mathrm{mL}^{-1}$ amphotericin B), phytohemagglutinin and formaldehyde were purchased from GIBCO, Grovemont Cir, Gaithersburg, MD USA. Sodium acetate trihydrate, fuming hydrochloric acid, acetic acid (glacial) and sodium carbonate were purchased from Merck KGaA, Darmstadt, Germany. Triton X-100, agarose (LMP), and 3-(4,5-dimethylthiazol-2-yl)-2,5-diphenyltetrazolium (MTS) for CellTiter $96^{\circ}$ Aqueous One Solution Cell Proliferation Assay were purchased from Promega, Madison, Wisconsin, USA. Lymphocyte separation medium was purchased from Lonza, Basilea, Suiza. The Anexin-V/IP kit (sc-4252), PVDF transfer membrane (sc-3723), Bcl-2 (C-21, sc-783), Bax (P-19, sc-526), pS46TP53 (Ser 46, sc-101,764), p-73 (recognizes all p73 isoforms raised against H-79, sc-7957), pY99-TP73 (Tyr 99, sc-101,769), H2AX (C-20, sc-54,606), pS139-H2A.X (Ser 139, sc-517,348), p21 (187, sc-817), $\beta$-tubulin (D-10, sc5274), goat anti-rabbit (sc-2004), and donkey anti-goat (sc-2020) were purchased from Santa Cruz Biotech, San Jose, California, USA. Goat anti-mouse (AP308P) and a chemiluminescence kit (Luminata Crescendo Western HRP substrate) were purchased from EMD-Millipore, Billerica, Massachusetts, USA.

\section{Lyophilization of the samples}

We used samples from the best-selling $\mathrm{HRCHs}$ mixtures [2]. Nine different mixtures were prepared, and the compositions are detailed in Table 1. The specimens were purchased from local markets in Loja, Ecuador and identified by Fani Tinitana, PhD. A voucher specimen was deposited in the Herbarium of Universidad Técnica Particular de Loja, Ecuador.

The HRCHs were prepared according to the traditional methods of Loja, the plants were boiled for $10 \mathrm{~min}$ in distilled water and then cooled to an ambient temperature. They were then placed in a laminar flow cabinet and transferred to sterilized glass vials. The samples were freeze-dried in a lyophilizer LABCONCO model 7,754,047 for approximately $48 \mathrm{~h}$. Finally, the samples were stored at $4{ }^{\circ} \mathrm{C}$.

\section{Phytochemical screening}

Phytochemical screening showed the presence of secondary metabolites (alkaloids, terpenoids, flavonoids, tannins, saponins, steroids, and quinones), primary metabolites 
Bailon-Moscoso et al. BMC Complementary and Alternative Medicine (2017) 17:539

Page 3 of 14

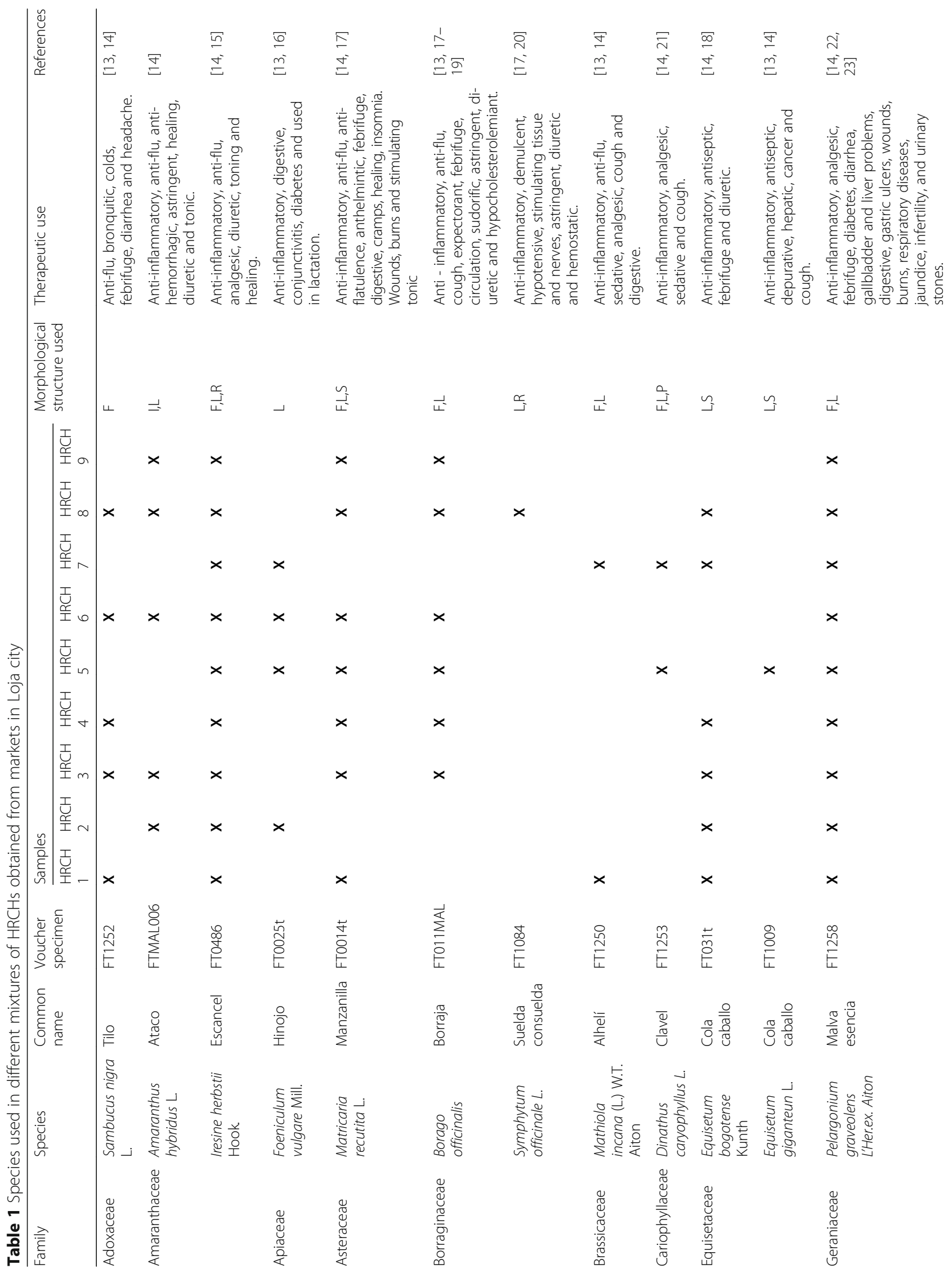


Bailon-Moscoso et al. BMC Complementary and Alternative Medicine (2017) 17:539

Page 4 of 14

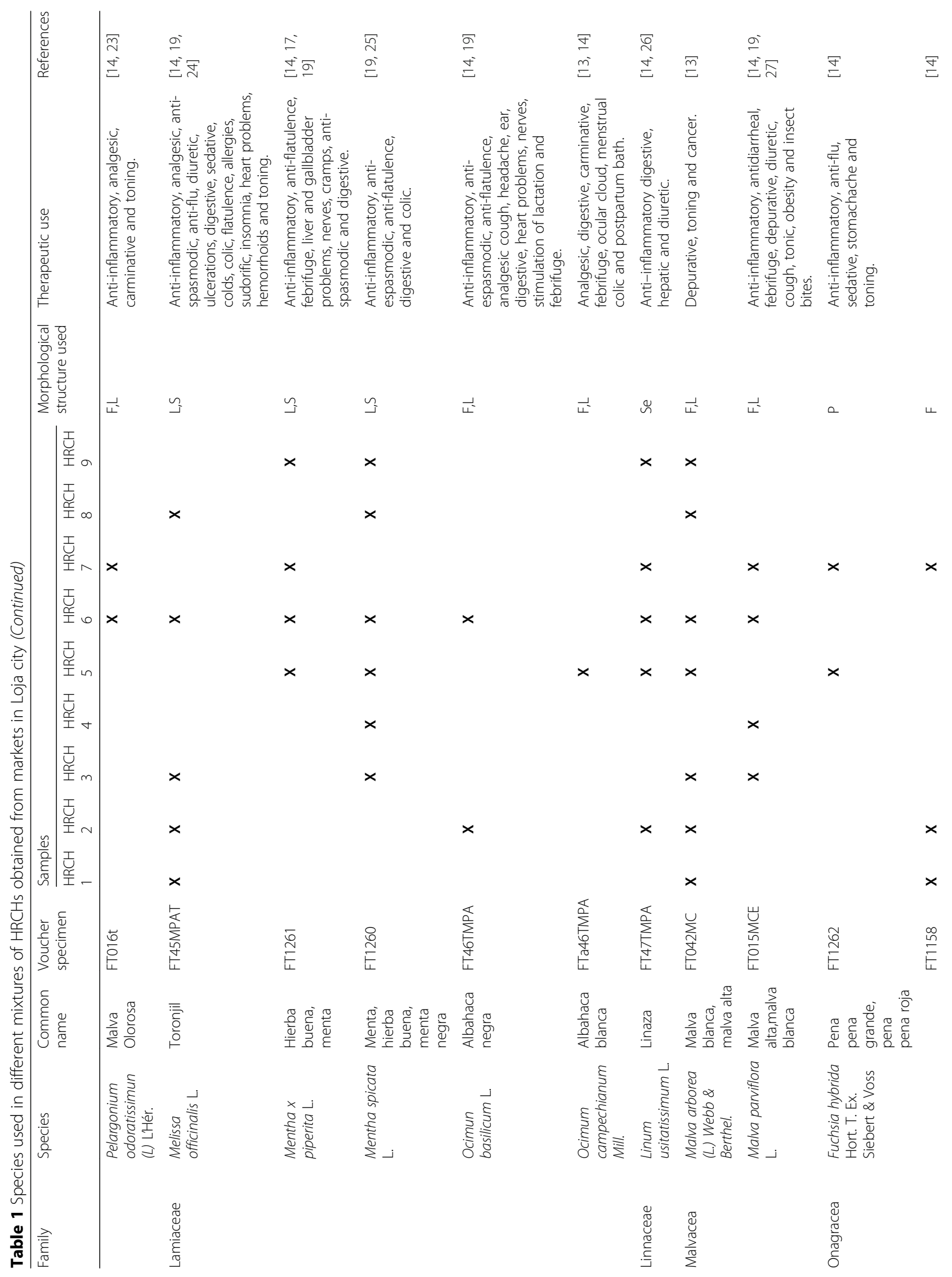




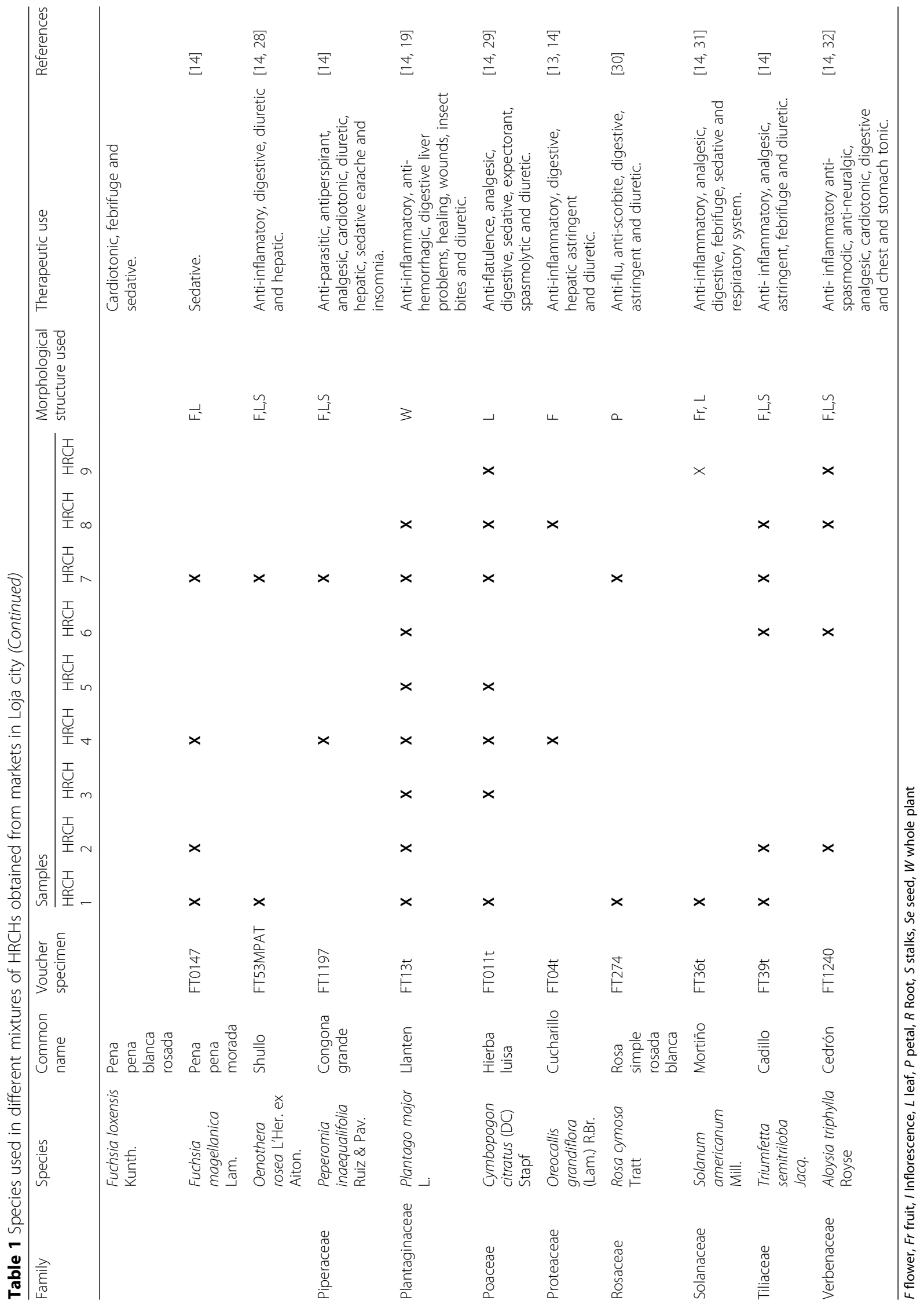


(proteins, carbohydrates, fats), and oils using standard procedures [41].

\section{Analysis of total phenolic content}

The total phenolic compounds were measured spectrophotometrically on a microplate reader $(\mathrm{EPOCH} 2$ BioTek, BioTek Instruments Inc., Highland Park, Winooski, USA) according to the Folin-Ciocalteu's method. This was applied to a 96-well microplate assay using gallic acid as a calibration standard [42]. A $50-\mu \mathrm{L}$ aliquot of the different concentrations of $\mathrm{HRCHs}$ samples and standards were added to $150 \mu \mathrm{L}$ of freshly prepared Folin-Ciocalteu reagent (1:4 v/v in distilled water) in a 96-well TR5003 cell culture plate (TrueLine, USA). After $10 \mathrm{~min}$ at $37^{\circ} \mathrm{C}, 50 \mu \mathrm{L}$ of the saturated solution of sodium carbonate was added to each well, and the plate was incubated for $10 \mathrm{~min}$ at $37{ }^{\circ} \mathrm{C}$. The absorbance of each solution was measured at $725 \mathrm{~nm}$ on a microplate reader (EPOCH 2 BioTek, BioTek Instruments Inc.). The standard curve was linear between 2 and $0.03 \mathrm{mM}$ gallic acid solution. The total amount of phenolics was calculated as mg gallic acid equivalent (GAE)/g of sample.

\section{DPPH radical scavenging assay}

The DPPH free radical scavenging activity was evaluated on a microplate analytical assay according to the literature [42, 43]. A $30 \mathrm{~mL}$ aliquot of the different concentrations of freeze-dried samples and standard were added to $270 \mu \mathrm{L}$ of DPPH in methanol solution $(100 \mu \mathrm{M})$ in a 96-well microplate assay. After incubation at $20{ }^{\circ} \mathrm{C}$ for $60 \mathrm{~min}$, the absorbance of each solution was determined at $515 \mathrm{~nm}$ using a microplate reader (EPOCH 2 BioTek, BioTek Instruments Inc.).

\section{Ferric reducing antioxidant power (FRAP) assay}

A FRAP assay was performed according to the literature $[42,44]$. This was applied to a 96-well microplate assay while monitoring the reduction of $\mathrm{Fe}^{3+}$-TPTZ to bluecolored $\mathrm{Fe}^{2+}$-TPTZ. Stock solutions of acetate buffer $(300 \mathrm{mM}) \mathrm{pH} 3.6, \mathrm{FeCl}_{3} \cdot 6 \mathrm{H}_{2} \mathrm{O}(20 \mathrm{mM})$ and $10 \mathrm{mM}$ TPTZ in $40 \mathrm{mM}$ in $\mathrm{HCl}(10 \mathrm{mM})$ were prepared. The fresh working solution was prepared by mixing ten volumes of acetate buffer, one volume TPTZ solution, and one volume $\mathrm{FeCl}_{3} \cdot 6 \mathrm{H}_{2} \mathrm{O}$ solution. This was then warmed to $37{ }^{\circ} \mathrm{C}$ before use. The FRAP working solution $(270 \mu \mathrm{L})$ was mixed and incubated with $30 \mu \mathrm{L} \mathrm{HRCHs/standards} \mathrm{for}$ $30 \mathrm{~min}$ in the dark. The absorbance of each solution was measured at $593 \mathrm{~nm}$ using a microplate reader $(\mathrm{EPOCH} 2$ BioTek, BioTek Instruments Inc.). The standard curve was linear between 400 and $25 \mu \mathrm{M}$ Trolox ${ }^{\text {Tix }}$ solution.

\section{Cells}

Cerebral astrocytoma (D384) cells were kindly received from Dr. Mayra Paolillo at the University of Pavia. Colon cancer (RKO) were kindly received from Dr. Patricia Ostrosky at the Universidad Nacional Autonoma de Mexico. Prostate cancer (PC-3), breast cancer (MCF-7), lung cancer (A-549) and Chinese Hamster Ovary (CHOK1) cells were purchased from the American Tissue Culture Collection (ATCC, Manassas, VA, USA).

Immortalized Chinese Hamster Ovary (CHO-K1) cells were cultured in HAM-F12 medium. The other cells were cultured in RPMI medium. These media were supplemented with $1 \%$ antibiotic-antimycotic, $2 \mathrm{mM} \mathrm{L-}$ glutamine, and 10\% FBS. The cultures were maintained at $37{ }^{\circ} \mathrm{C}$ in a humid atmosphere at $5 \% \mathrm{CO}_{2}$. The doubling times of the PC-3, MCF-7, RKO, and A-549 cells were established as $24 \mathrm{~h}$; the $\mathrm{CHO}-\mathrm{K} 1$ and $\mathrm{D}-384$ cells were $16 \mathrm{~h}$.

Human peripheral blood lymphocytes (PBL) were isolated by density gradient centrifugation with lymphocyte separation medium from whole peripheral blood from three donors. All donors gave informed written consent to use human blood samples for research purposes (View Ethics approval and consent to participate). The donors had the following characteristics: below age 30, healthy, non-smokers, and with unknown exposure to genotoxic chemicals or radiation. PBL were cultured at $37{ }^{\circ} \mathrm{C}$ and $5 \% \mathrm{CO}_{2}$ in RPMI-1640 supplemented with $0.5 \%$ phytohemagglutinin; $1 \%$ antibiotic antimycotic, $2 \mathrm{mM} \mathrm{L}$-glutamine, and 10\% FBS. The cultures were maintained at $37{ }^{\circ} \mathrm{C}$ in a humid atmosphere at $5 \% \mathrm{CO}_{2}$.

\section{Cell viability assay}

Cell viability was analyzed with a MTS assay to assess the viability and/or the metabolic state of the cancer cells based on mitochondrial respiratory activity. A total of $5 \times 10^{3}$ cells were seeded into each well of 96-well plates and allowed to adhere for $24 \mathrm{~h}$. After $24 \mathrm{~h}$, the cells were treated with freeze-dried $\mathrm{HRCHs}$ at $50 \mu \mathrm{g} \cdot \mathrm{mL}^{-1}$. Each concentration/assay was performed in triplicate. Negative control cells were treated with the DMSO vehicle to a final concentration of $0.1 \% v / \mathrm{v} ; 0.5 \mu \mathrm{M}$ doxorubicin was used as a positive control. The cells were then incubated with the treatments for $48 \mathrm{~h}$. After $48 \mathrm{~h}$, MTS $\left(5 \mathrm{mg} \cdot \mathrm{mL}^{-1}\right.$ ) was added, and the cells were further incubated for $2 \mathrm{~h}$ in the dark at $37{ }^{\circ} \mathrm{C}$. Absorbance was measured at $492 \mathrm{~nm}$ versus a reference wavelength of $650 \mathrm{~nm}$. In cell lines with a inhibition percentage over $30 \%$, doses of $15,45,60,75$ and $100 \mu \mathrm{g} \cdot \mathrm{mL}^{-1}$ of each $\mathrm{HRCHs}$ were applied, and the MTS assay was used to measure the inhibitory concentration $50\left(\mathrm{IC}_{50}\right)$ using nonlinear regression.

\section{Annexin V-FITC/PI apoptosis assay}

We next quantified apoptotic cells using an Annexin VFITC/PI apoptosis detection kit [45]. In brief, the D384 cells were seeded in 6-well plates at a density of $1 \times 10^{5}$ 
cells/well. After treatment at the $\mathrm{IC}_{50}$ for $48 \mathrm{~h}$, both adherent and floating cells were harvested and stained with Annexin V-FITC/PI according to the manufacturer's procedure. The samples were analyzed with fluorescence microscopy and an excitation wavelength of $475 \mathrm{~nm}$ (Zeiss Axioskop 2 plus); 200 cells were counted.

\section{Western blotting analysis}

Total protein extraction, quantification, and immunoblots were performed as described [46]. Briefly, $50 \mu \mathrm{g}$ of total protein were separated by $12-15 \%$ SDS-PAGE and transferred to a PVDF membrane (IPVH00010, Immobilon-P, $0.45 \mu \mathrm{m}$, Millipore). Rabbit polyclonal antibodies against Bcl-2, Bax, pS46-TP53, p-73, and pY99-TP73 were used with mouse poyclonal antibodies against pS139-H2AX, p21, and $\beta$-tubulin and a goat polyclonal antibody against $\mathrm{H} 2 \mathrm{AX}$; all antibodies were used at the dilution factor recommended by the manufacturer with the appropriate goat anti-rabbit, goat anti-mouse, and donkey anti-goat horseradish peroxidase-conjugated immunoglobulins (1:5000). Immunoreactive bands were visualized using a chemiluminescence kit Luminata Crescendo Western HRP substrate. Quantitative analysis of the proteins used a C-Digit Blot Scanner (LICOR).

\section{Measurement of reactive oxygen species (ROS)}

The detection of ROS used 2'7'-dichlorodihydrofluorescein diacetate (DCHF-DA) [47]. Previously, CHO-K1 cells were cultured in 96-well multi-plates in HAM-F12 culture medium supplemented for $16 \mathrm{~h}$. The cells were incubated with $\mathrm{H}_{2}$ DCFDA $(20 \mu \mathrm{M})$ and HBSS for $30 \mathrm{~min}$ at $37{ }^{\circ} \mathrm{C}$. The cells were exposed to doses of $1000 \mu \mathrm{g} \cdot \mathrm{mL}-1$ of the HRCHs and/either $\mathrm{H}_{2} \mathrm{O}_{2}(5 \mathrm{mM})$ as a positive control; HBSS was applied as a negative control. The multiplate was incubated for $2 \mathrm{~h}$ at $37^{\circ} \mathrm{C}$. DCFDA fluoride was measured after exposure on a Fluoroskan Ascent (Thermo Fisher Scientific) fluorometer at a $\lambda_{\mathrm{ex}}$ of $485 \mathrm{~nm}$ and $\lambda_{\mathrm{em}}$ of $528 \mathrm{~nm}$.

\section{Alkaline comet assay}

The alkaline comet assay was performed as reported elsewhere with minor modifications [48]. After $16 \mathrm{~h}$ of culturing the $\mathrm{CHO}-\mathrm{K} 1$, two experimental conditions were performed. The first was only HRCHs $\left(1000 \mu \mathrm{g} \cdot \mathrm{mL}^{-1}\right)$, and the second was concurrent treatment for $16 \mathrm{~h}$ of HRCHs $\left(1000 \mu \mathrm{g} \cdot \mathrm{mL}^{-1}\right)$ and $\mathrm{H}_{2} \mathrm{O}_{2}(5 \mathrm{mM})$. The CHO-K1 cell cultures were mixed with $150 \mu \mathrm{L}$ low-melting agarose $(0.5 \%)$ and added to microscope slides. The slides were immersed in a cooled lysing solution (10\% DMSO, $1 \%$ Triton X-100, $2.5 \mathrm{M} \mathrm{NaCl}, 100 \mathrm{mM}$ EDTA, and $10 \mathrm{mM}$ Tris) for $12 \mathrm{~h}$ at $4{ }^{\circ} \mathrm{C}(\mathrm{pH} 10)$. All steps after lysis were performed in the dark to prevent additional DNA damage by another factors. All slides were submerged in electrophoresis buffer solution $(300 \mathrm{mM} \mathrm{NaOH}$ and $1 \mathrm{mM}$ $\mathrm{Na}_{2} \mathrm{EDTA}$ ) ( $\mathrm{pH} \mathrm{13)} \mathrm{for} 20 \mathrm{~min}$; this allowed the DNA to unwind. Electrophoresis conditions were $25 \mathrm{~V}$ and $300 \mathrm{~mA}$ for $20 \mathrm{~min}$. A buffer solution was used to neutralize the slides after electrophoresis, $(0.4 \mathrm{M}$ Tris, $\mathrm{pH}$ 7.5). Each slide received $\mathrm{EtBr}\left(60 \mu \mathrm{L}, 30 \mu \mathrm{g} \cdot \mathrm{mL}^{-1}\right)$ with a cover glass. The length tail of DNA damage was estimated using a ZEISS-Axioskop 2 plus fluorescence microscope, and 100 cells were scored on each slide and confirmed with Comet assay VI software.

\section{Micronucleus assay by cytokinesis-block (CBMN assay)}

The CBMN test was performed as reported elsewhere with minor modifications [49]. After $16 \mathrm{~h}$ of culturing $\mathrm{CHO}-\mathrm{K} 1$, three experimental conditions were performed. The first was only $\mathrm{HRCHs}$ and cytochalasin B at a final concentration of $2 \mu \mathrm{g} / \mathrm{ml}$. The second was $24 \mathrm{~h}$ with $\mathrm{HRCH}$, mytomicin $\mathrm{C}$ (MMC), and cytochalasin $\mathrm{B}$. The last was MMC for $3 \mathrm{~h}$ followed by $\mathrm{HRCHs}$ and cytochala$\sin$ B. After $16 \mathrm{~h}$ of incubation, the cells were fixed in cold $\left(-20^{\circ} \mathrm{C}\right)$ ethanol $96^{\circ}$ for 5 min washed with distilled water, re-fixed in acetic acid:methanol $(1: 3 v / v)$ for $5 \mathrm{~min}$, and washed. The fixed cells were stained with a drop of DAPI (4',6'-diamidino-2-phenylindole $\mathrm{HCl}$,

Table 2 Preliminary phytochemical studies of HRCHs

\begin{tabular}{|c|c|c|c|c|c|c|c|c|c|}
\hline \multirow[t]{2}{*}{ Test } & \multicolumn{9}{|l|}{ Sample } \\
\hline & $\mathrm{HRCH} 1$ & $\mathrm{HRCH} 2$ & $\mathrm{HRCH} 3$ & $\mathrm{HRCH} 4$ & $\mathrm{HRCH} 5$ & $\mathrm{HRCH} 6$ & $\mathrm{HRCH} 7$ & $\mathrm{HRCH} 8$ & $\mathrm{HRCH} 9$ \\
\hline Proteins & - & - & - & - & - & - & - & - & - \\
\hline Carbohydrates & - & - & - & - & - & - & - & - & - \\
\hline Fats & - & - & - & - & - & - & - & - & - \\
\hline Alkaloids & + & - & - & ++ & - & + & ++ & ++ & ++ \\
\hline Terpenoids-Steroids & - & + & + & + & + & + & + & + & + \\
\hline Flavonoids & - & + & + & + & + & + & + & + & + \\
\hline Saponnins & + & + & + & + & + & + & + & + & + \\
\hline Quinones & + & + & + & + & + & + & - & - & + \\
\hline Tannins $^{a}$ & - & - & - & - & + & - & - & + & - \\
\hline
\end{tabular}

$+++=$ Very positive,$++=$ Strong positive,$+=$ Fair positive, $-=$ Absent

a'Type: pyrocatechol 
Table 3 Total phenolic content and total antioxidant capacity of the HRCHs

\begin{tabular}{llll}
\hline Sample & TPC & DPPH & FRAP \\
& mg GAE $\cdot g^{-1}$ & TEAC $^{a} \mu \mathrm{mol} \mathrm{TE} \cdot \mathrm{g}^{-1}$ & TEAC $\mu \mathrm{mol} \mathrm{TE} \cdot \mathrm{g}^{-1}$ \\
\hline HRCH 1 & $106.39 \pm 0.1$ & $1382.18 \pm 27.7$ & $71.35 \pm 3.1$ \\
HRCH 2 & $147.32 \pm 1.1$ & $1126.91 \pm 43.3$ & $105.51 \pm 1.9$ \\
HRCH 3 & $143.40 \pm 2.3$ & $999.64 \pm 32.0$ & $101.65 \pm 0.4$ \\
HRCH 4 & $128.39 \pm 2.2$ & $230.96 \pm 11.8$ & $85.59 \pm 2.0$ \\
HRCH 5 & $136.80 \pm 2.2$ & $858.33 \pm 37.9$ & $96.82 \pm 0.6$ \\
HRCH 6 & $143.03 \pm 1.1$ & $584.23 \pm 1.3$ & $103.23 \pm 0.9$ \\
HRCH 7 & $138.17 \pm 2.3$ & $1092.36 \pm 69.1$ & $99.66 \pm 6.9$ \\
HRCH 8 & $147.31 \pm 2.2$ & $1109.79 \pm 31.9$ & $110.34 \pm 1.4$ \\
HRCH 9 & $130.33 \pm 1.1$ & $919.64 \pm 46.6$ & $86.21 \pm 1.3$ \\
\hline
\end{tabular}

${ }^{\mathrm{a}} \mathrm{TEAC}=$ Trolox equivalent (TE) antioxidant concentration

Serva), dissolved in Tris-buffer ( $\mathrm{pH} 7.5$ ) at $2 \mu \mathrm{g} / \mathrm{ml}$. The preparations were evaluated with an Axioskop 2 plus microscope (Zeiss, Germany) equipped with a fluorescence illuminator (HBO50 lamp); the filter set was $365 \mathrm{~nm}$ excitation and $420 \mathrm{~nm}$ emission (specific for DAPI). Phase contrast was also used, and analysis was performed at high magnification for $\sim 400 \AA$ resolution. To facilitate discrimination of micronuclei $(\mathrm{MN})$ and differentiation between mononucleated, binucleated (which divided once after exposition), and polynucleated cells (which divided twice or more). Scoring was performed blindly. The number of binucleated cells per dish was evaluated after scoring 2000 consecutive cells distributed as a monolayer according to the criteria described previously [50].

\section{Statistical analysis}

All data were reported as the mean \pm SEM of independent experiments. The statistical significance was obtained with one-way analysis of variance (ANOVA) followed by a Dunnet post-test; treated cultures were compared to controls. Statistical analyses were carried out in GraphPad Prism 4 (GraphPad Software, San Diego, CA).

\section{Results}

The results of phytochemical screening tests on freezedried HRCHs samples revealed the presence or absence of main secondary metabolites and other phytochemicals based on the presence or absence of expected color changes (Table 2). The freeze-dried samples contained saponins, flavonoids (except HRCH 1), terpenoids (except HRCH 1), quinones (except $\mathrm{HRCH} 7$ and $\mathrm{HRCH}$ 8), and alkaloids (except $\mathrm{HRCH} 2$, HRCH 3 and $\mathrm{HRCH}$ 5).

The antioxidant capacity was measured because of the presence of flavonoids and quinones in almost all $\mathrm{HRCH}$ samples. The total phenolic contents (TPC) of the $\mathrm{HRCHs}$ were initially estimated as $\mathrm{mg} \mathrm{GAE} / \mathrm{g}$ of sample by employing the Folin-Ciocalteu method; values were between 106 and $147 \mathrm{GAE} / \mathrm{g}$ (Table 2).

The antioxidant activity of nine $\mathrm{HRCHs}$ were evaluated in detail via DPPH and FRAP assays (Table 3). The Trolox equivalent antioxidant capacity (TEAC) values were calculated as mmol Trolox equivalent (TE)/g of freeze-dried $\mathrm{HRCH}$ to confirm the high antioxidant capacity of seven of the nine HRCHs samples $(\sim 1000$ mmoles TE/g of freeze-dried) except $\mathrm{HRCH} 4$ and $\mathrm{HRCH} 6$. The ferric ion reducing capacity of the nine $\mathrm{HRCHs}$ was evaluated with total antioxidant capacity values ranging between 71 and $110 \mathrm{mmol} \mathrm{TE} / \mathrm{g}$ of freeze-dried samples.

Table 4 Cytotoxic effect of the HRCHs on cells exposed to $50 \mu \mathrm{g} \cdot \mathrm{mL}^{-1}$

\begin{tabular}{|c|c|c|c|c|c|c|c|}
\hline \multirow[b]{4}{*}{ Sample } & \multicolumn{7}{|c|}{ Percentages of inhibition \pm (SEM) } \\
\hline & \multicolumn{5}{|c|}{ Tumor human } & \multirow[t]{2}{*}{ Immortalized cell } & \multirow[t]{2}{*}{ Normal Human cell } \\
\hline & Lung & Astrocytoma & Breast & Prostate & Colon & & \\
\hline & A-549 & D-384 & MCF-7 & $P C-3$ & RKO & $\mathrm{CHO}-\mathrm{K} 1$ & PBL \\
\hline$\overline{\mathrm{HRCH}} 1$ & $1.7 \pm 1.2$ & $36.7 \pm 4.0^{(* * *)}$ & $5.1 \pm 1.0$ & $14.7 \pm 5.4$ & $2.8 \pm 0.7$ & N.A. & N.A. \\
\hline $\mathrm{HRCH} 2$ & $1.9 \pm 2.1$ & $40.8 \pm 14.3^{(* * *)}$ & $7.1 \pm 1.3^{(*)}$ & $26.9 \pm 6.6^{(*)}$ & $3.9 \pm 2.12$ & N.A. & N.A. \\
\hline $\mathrm{HRCH} 3$ & $1.6 \pm 0.5$ & $3.3 \pm 1.6$ & $0.3 \pm 1.7$ & N.A. & $0.4 \pm 1.3$ & N.A. & N.A. \\
\hline $\mathrm{HRCH} 4$ & N.A. & $2.0 \pm 1.7$ & $2.7 \pm 1.8$ & N.A. & N.A. & N.A. & N.A. \\
\hline $\mathrm{HRCH} 5$ & N.A. & $2.5 \pm 1.7$ & $4.6 \pm 1.7$ & N.A. & N.A. & N.A. & N.A. \\
\hline $\mathrm{HRCH} 6$ & $2.4 \pm 4.6$ & N.A. & $0.2 \pm 1.2$ & N.A. & N.A. & $3.0 \pm 0.3$ & N.A. \\
\hline $\mathrm{HRCH} 7$ & N.A. & $30.0 \pm 0.7^{(* * *)}$ & N.A & N.A. & $4.1 \pm 2.2^{(*)}$ & N.A. & N.A. \\
\hline $\mathrm{HRCH} 8$ & $5.1 \pm 12$ & $32.6 \pm 5.0^{(* * *)}$ & $6.9 \pm 0.08^{(*)}$ & N.A. & $0.5 \pm 1.5$ & N.A. & N.A. \\
\hline $\mathrm{HRCH} 9$ & $4.4 \pm 4.7$ & $60.7 \pm 0.04^{(* * *)}$ & $0.7 \pm 0.2$ & $2.2 \pm 9.6$ & N.A. & N.A. & N.A. \\
\hline $\begin{array}{l}\text { Doxorubicin } \\
(0.5 \mu \mathrm{M})\end{array}$ & $86.9 \pm 6.2^{(* * *)}$ & $76.1 \pm 2.6^{(* * *)}$ & $59.1 \pm 7.4^{(* * *)}$ & $71.5 \pm 1.5^{(* * *)}$ & $53.4 \pm 3.6\left(^{* * *}\right)$ & $8.5 \pm 0.3$ & N.A \\
\hline
\end{tabular}

N.A. No activity. Each data is given as the mean and its standard error (SEM) of at least three independent experiments. Data were analyzed by repeated ANOVA followed by Bonferroni post-test. Symbols denote statistically significant differences: ${ }^{*} p<0.01,{ }^{* *} p<0.001$, and ${ }^{* * *} p<0.0001$ with respect to control and between $\mathrm{HRCH}$ 
Table 5 Half maximal inhibitory concentration $\left(\mathrm{IC}_{50}\right)$ of $\mathrm{HRCHs}$ on D384 cells

\begin{tabular}{ll}
\hline Sample & $I_{50} \pm$ SEM $\mu \mathrm{g} / \mathrm{ml}$ \\
& Astrocytoma (D-384) \\
\hline HRCH 1 & $74.2 \pm 0.7$ \\
$\mathrm{HRCH} 2$ & $98.7 \pm 7.4$ \\
$\mathrm{HRCH} 7$ & $71.6 \pm 1.8$ \\
$\mathrm{HRCH} 8$ & $122.7 \pm 4.3$ \\
$\mathrm{HRCH} 9$ & $41.5 \pm 6.2$ \\
Doxorubicin & $0.1 \pm 0.2$ \\
\hline
\end{tabular}

Each data is given as the mean and its standard error (SEM) of at least three independent experiments

We used a MTS assay to evaluate the inhibitory activity of $\mathrm{HRCHs}$ on cell growth to determine whether HRCHs could affect tumor cell survival. There was no inhibitory effect on cell growth with PBL and CHO-K1 at $50 \mu \mathrm{g} \cdot \mathrm{mL}^{-1}$ (Table 4). None of the HRCHs inhibited growth by more than $30 \%$ in A-549, RKO, MCF-7, and PC-3 cell lines. In D-384 cells, five ( $\mathrm{HRCH} 1, \mathrm{HRCH} 2$, $\mathrm{HRCH} 7, \mathrm{HRCH} 8$, and $\mathrm{HRCH} 9$ ) of the $9 \mathrm{HRCHs}$ generated cell inhibition greater than $30 \%$.

The data in Table 5 show the $\mathrm{IC}_{50}$ of the active $\mathrm{HRCHs}$ in $\mathrm{D}-348$ cells. The $\mathrm{IC}_{50}$ range of effective HRCHs was 41 to $122 \mu \mathrm{g} \cdot \mathrm{mL}^{-1}$. The least potent was $\mathrm{HRCH} 8$ with $122.7 \pm 4.3 \mu \mathrm{g} \cdot \mathrm{mL}^{-1}$, and the most potent was $\mathrm{HRCH} 9$ with $41.5 \pm 6.2 \mu \mathrm{g} \cdot \mathrm{mL}^{-1}$.

We continued studies of the cytotoxic effect produced by the most prominent $\mathrm{HRCHs}$ whose $\mathrm{IC}_{50}$ are less than $80 \mu \mathrm{g} \cdot \mathrm{mL}^{-1}$ (HRCH 1, HRCH 7, and HRCH 9). The D384 cells treated with negative control and $\mathrm{IC}_{50}$ of $\mathrm{HRCHs}$ for $48 \mathrm{~h}$ are shown in Fig. 1a including the morphological changes. Figure $2 b$ shows fluorescence microscopy data for D384 cells using the Annexin V-PI assay. We observed a decrease in the percentage of viable cells as well as an increase in the percentage of cells in early apoptosis: $\mathrm{HRCH} 1$ resulted in $\sim 22 \%$ inhibition, HRCH 7 was $\sim 27 \%$ and HRCH 9 was $\sim 19 \%$. In cells exposed to $\mathrm{HRCH}$ 9, there was an increase in the percentage of cells in late apoptosis $(\sim 21 \%)$ compared with control cells $(\sim 1 \%)$ (Fig. 1b). HRCHs can modulate proteins related to death by apoptosis after evaluating Bax (pro-apoptotic) and Bcl-2 (anti-apoptotic) proteins. In both $\mathrm{HRCH} 1$ and $\mathrm{HRCH}$ 9, there was an increased $\mathrm{Bax} / \mathrm{Bcl}-2$ ratio with respect to the negative control. Both Bax and Bcl-2 increased in cells exposed to HRCH 7 (Fig. 2a-b).

Accumulating evidence shows that p53 family members ( $553, \mathrm{p} 63$, and p73) play a fundamental role in the regulation of cell cycle arrest, apoptosis, autophagy, and metabolism in tumor cells exposed to stress-induced and DNA damaging agents of various origins [51-54]. Therefore, we examined whether $\mathrm{HRCHs}$ induced cell death and were implicated in the expression of these transcriptional factors in D384 cells. Fig. 2a-b show increased expression of $\mathrm{p}-73 \alpha$ and $\mathrm{p}-73 \beta$ in all $\mathrm{HRCHs}$ ( $\mathrm{HRCH} \mathrm{1,} \mathrm{HRCH} 7$ and $\mathrm{HRCH} 9$ ) as well as a decrease in $\triangle \mathrm{Np}-73$ except for $\mathrm{HRCH} 7$. It is also clear that this effect is modulated by phosphorylation of p53 when $\mathrm{HRCH} 1$ and $\mathrm{HRCH} 7$ are applied. In all cases, p21-a cell cycle arrest indicator-is activated. Fig. 2a-b increase with respect to the control of histones $(\gamma-\mathrm{H} 2 \mathrm{AX}$ and $\mathrm{p}-$ $\gamma$-H2AX) related to DNA.

After observing DNA damage in tumor cells, we next studied if it occurred in normal cells using CHO-K1 cells serve as a model. We first studied the induction of ROS and subsequent genotoxicity damage and genotoxic

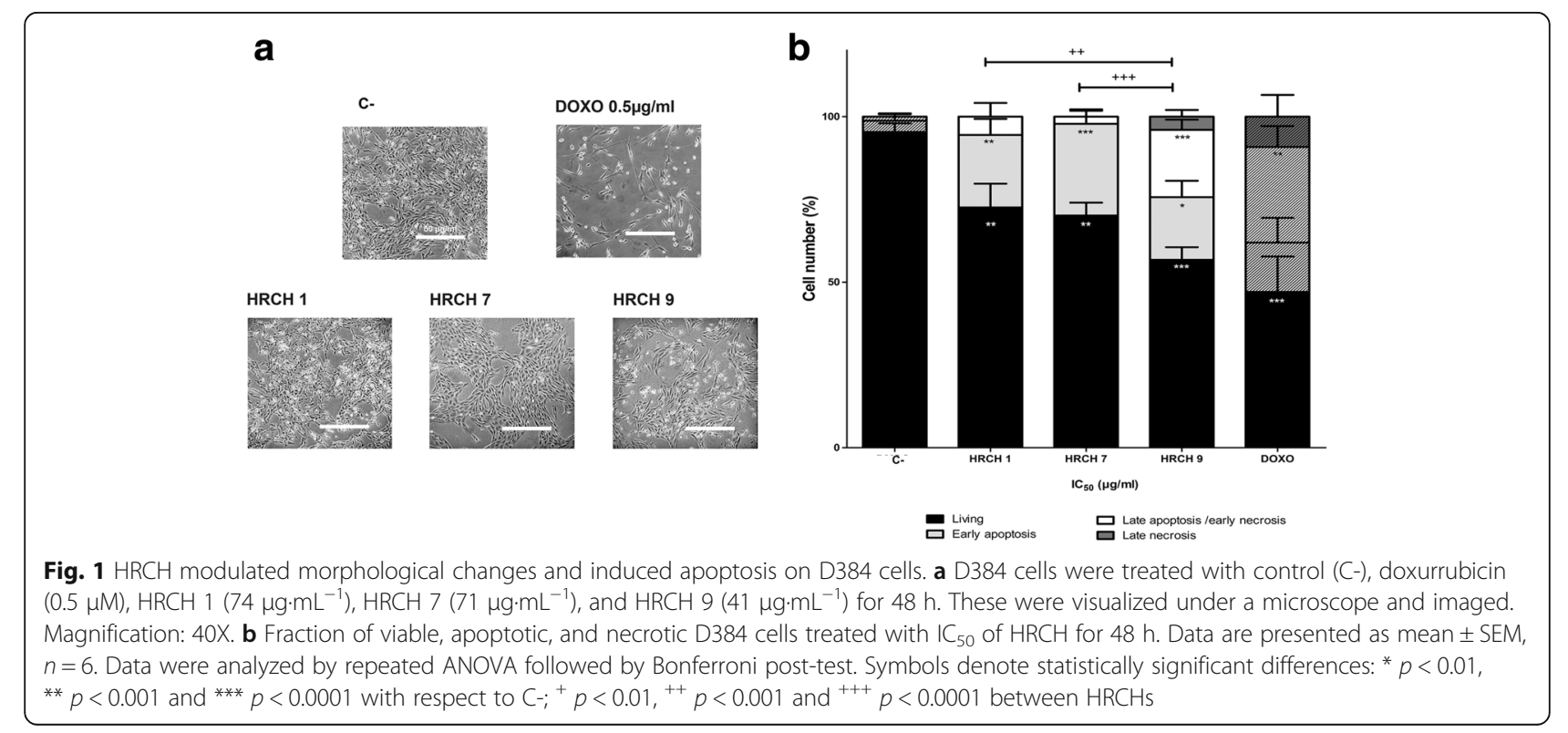




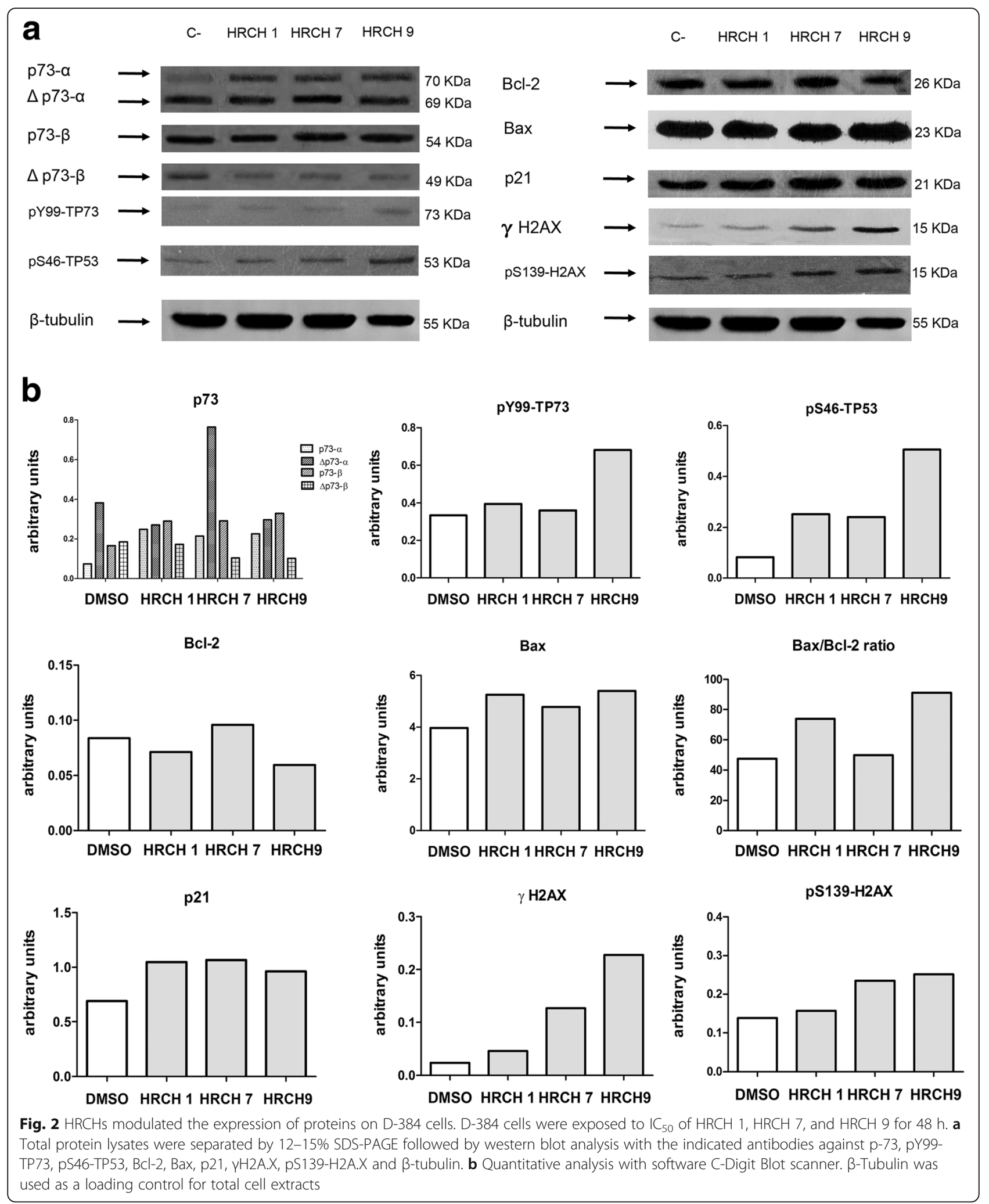

and antigenotoxic activities. The $\mathrm{CHO}-\mathrm{K} 1$ cells showed increased ROS (Fig. 3a), but this was $\sim 50 \%$ lower than the values produced in a ROS-inducing agent $\left(\mathrm{H}_{2} \mathrm{O}_{2}\right)$.
Genotoxic and antigenotoxic activity were established with a comet assay and MNCB. Comet tail length was increased in CHO-K1 cells in all cases treatment with 

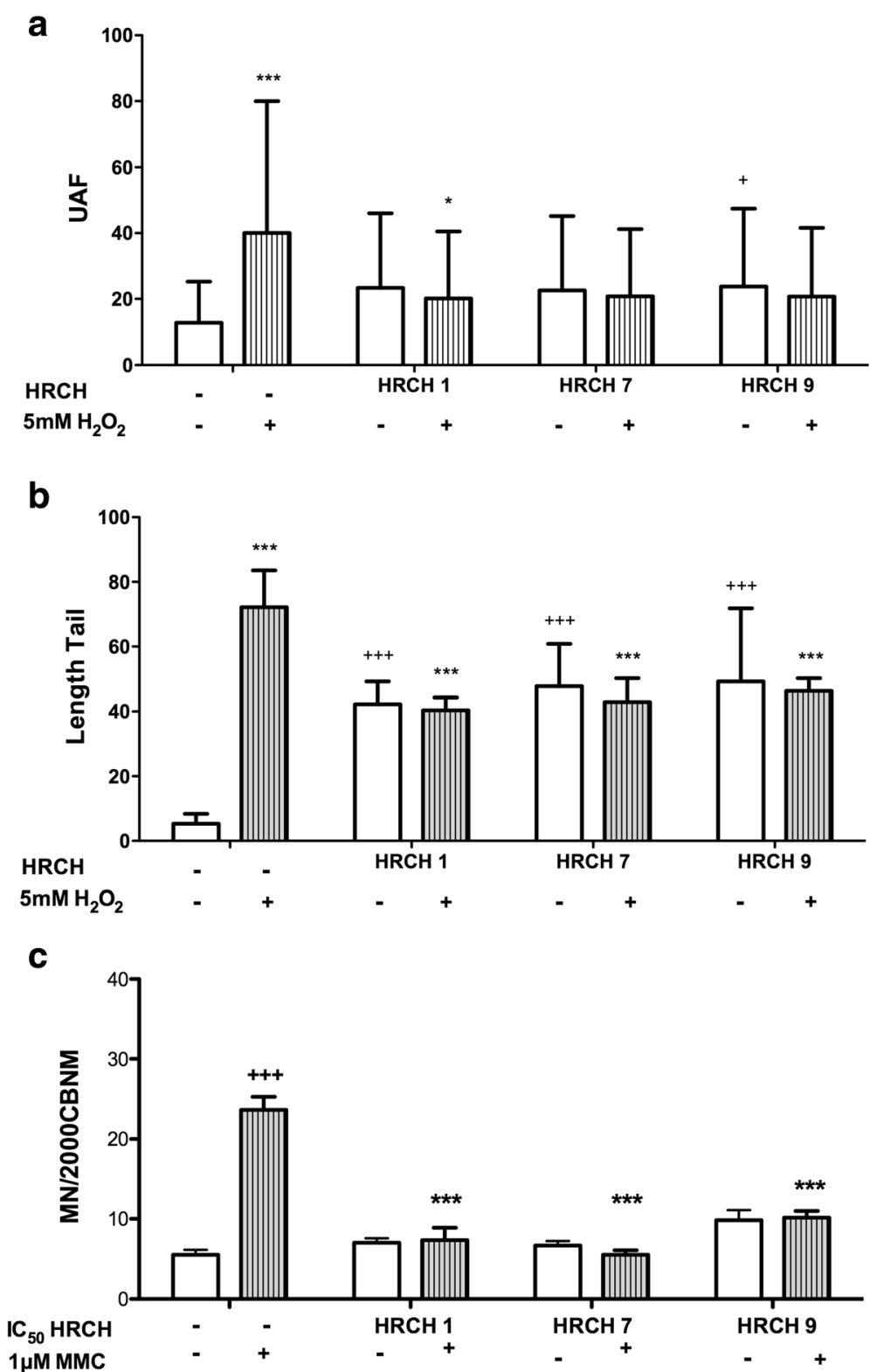

Fig. 3 Production and inhibition of ROS, genotoxic, and anti-genotoxic activity on CHO-K1 cells exposed to HRCHs. a Reactive oxygen species of $\mathrm{HRCHs}$ with $\mathrm{HRCHs}\left(1000 \mu \mathrm{g} \cdot \mathrm{mL}^{-1}\right)$ and inhibition of ROS production with $\mathrm{HRCHs}\left(5 \mathrm{mM} \mathrm{H} \mathrm{O}_{2}+1000 \mu \mathrm{g} \cdot \mathrm{mL}^{-1}\right)$. AUF: Arbitrary units of fluorescence. $\mathbf{b}$ Comet assay measured with tail length exposed to $1000 \mu \mathrm{g} \cdot \mathrm{mL}^{-1} \mathrm{HRCHs}$ and anti-genotoxic activity exposed to co-treatment with $\mathrm{HRCH}(1000 \mu \mathrm{g} / \mathrm{ml})+$ $5 \mathrm{mM} \mathrm{H}_{2} \mathrm{O}_{2}$. c Number of Mn for 2000 BNC to $1000 \mu \mathrm{g} \cdot \mathrm{mL}^{-1} \mathrm{HRCHs}$ as well as anti-genotoxic activity exposed to co-treatment with $\mathrm{HRCH} \mu \mathrm{g} \cdot \mathrm{mL}^{-1}+$ $1 \mathrm{mM}$ MMC. The data are presented as the mean $\pm \mathrm{SEM}, n=6$. Data were analyzed by repeated ANOVA followed by Bonferroni post-test. Symbols denote statistically significant differences: $+++p<0.0001$ with respect to control (C-) and between HRCH samples. Symbols denote statistically significant differences: ${ }^{*} p<0.01$, ${ }^{* *} p<0.001$, and ${ }^{* *} p<0.0001$ with respect to $\mathrm{H}_{2} \mathrm{O}_{2}$ and between HRCHs

horchatas (Fig. 3b). However, relative to the $\mathrm{H}_{2} \mathrm{O}_{2}$ control, the DNA damage was 30\% ( $\mathrm{HRCH} 9)$ and $40 \%$ ( $\mathrm{HRCH} 1$ and $\mathrm{HRCH} 7$ ) lower.

When we measured the genotoxic damage via the MNBN test, we observed no increase with respect to basal damage via a DNA damage-inducing agent such as MMC. The damage decreases even at basal levels (Fig. 3c) with HRCHs. To determine if it is due to a direct interaction with the genotoxic agent and the components of the $\mathrm{HRCHs}$, we used the inducing agent (MMC) for $3 \mathrm{~h}$ followed by HRCHs. The HRCH 7 maintained the antigenotoxic effect (Fig. 4).

\section{Discussion}

This study describes the cytotoxicity activity of five horchata mixtures $(\mathrm{HRCH} \mathrm{1,} \mathrm{HRCH} 2, \mathrm{HRCH} 7, \mathrm{HRCH} 8$, 


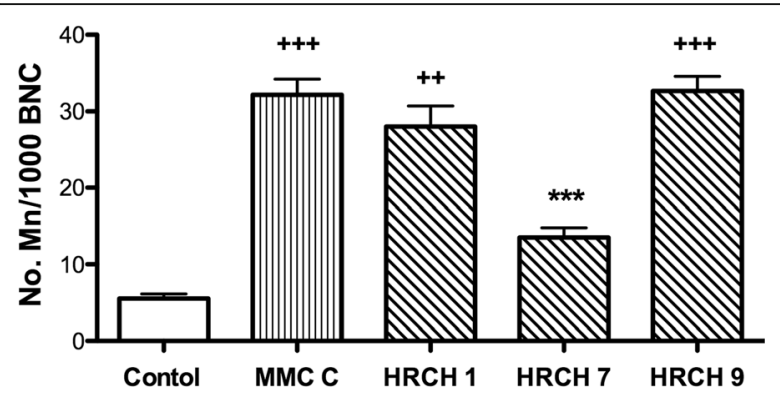

Fig. 4 Anti-genotoxic activity on $\mathrm{CHO}-\mathrm{K} 1$ cells exposed to $\mathrm{HRCHs}$ post-treatment with MMC. The number of Mn for 1000 BNC exposed to $1 \mathrm{mM} \mathrm{MMC}$ and $1000 \mu \mathrm{g} \cdot \mathrm{mL}^{-1} \mathrm{HRCHs}$ for $3 \mathrm{~h}$. Data are presented as mean $\pm S E M, n=6$. Data were analyzed by repeated ANOVA followed by Bonferroni post-test. Symbols denote statistically significant differences: $+++p<0.0001$ with respect to control (C-) and *** $p<0.0001$ with respect to MMC and between $\mathrm{HRCHs}$

and $\mathrm{HRCH}$ 9) on brain astrocytoma cells (D-384). This effect is not surprising because these products are sold as a traditional "brain tonic" [2]. However, $\mathrm{HRCHs}$ have a high antioxidant capacity. The phenolic content is markedly higher than other plants [21] and correlates well with the high antioxidant capacity of HRCHs. Likewise, HRCHs have a strong radical scavenging ability-even better than vitamins $C$ and $E$ [55]. The antioxidant properties are protective against neuronal damage mediated by oxidative stress [56-59]. We emphasize that the same cytotoxic doses do not affect normal cells (CHO-K1 and PBL). This suggests that antioxidants in certain medicinal plants protect normal cells while killing neoplastic cells $[60,61]$. The most potent mixtures ( $\mathrm{HRCH} 1, \mathrm{HRCH} 7$, and $\mathrm{HRCH}$ 9) induce apoptosis, but the active ingredients are not clear because the product is a mixture. Some plants and their secondary metabolites have been previously described as inducers of apoptosis [35-59].

Post-translational modifications such as phosphorylation in the Serine 46/Tyrosine 99 of p53/P73 are critical because they facilitate binding with more affinity to pro-apoptotic proteins like Bax [54]. Their overexpression increases the $\mathrm{Bax} / \mathrm{Bcl}-2$ ratio allowing the release of cytochrome $\mathrm{C}$ from mitochondria to promote apoptosis [66]. Changes in protein expression are related to the percentages of early and late stages of apoptosis as can be seen in the differences between HRCH 7 and $\mathrm{HRCH} 9$.

HRCHs inhibited ROS (in vitro in cells) and antigenotoxic (comet assay) and anticlastogenic (CBMN) effects. This could be due to an interaction with the genotoxic agents. However, when we tested different times between $\mathrm{HRCHs}$ and the alkylating agent, the anticlastogenic effect is maintained by HRCH 7 similar to various phytochemicals [62-65, 67-70]. Oxidative stress, chronic inflammation, and genomic instability events are predisposing factors for neoplastic transformation [71-73], and perturbation of these events may interfere with the malignant progression of cells. $\mathrm{HRCH}$ can enhance the genomic stability of cells and protect the cells against chromosomal and DNA damage induced by various genotoxic agents to gain insight into its potential use as a chemopreventive mixture.

\section{Conclusions}

Horchata is a traditional drink in southern Ecuador that contains various medicinal plants and cytotoxic activity toward astrocytoma cells inducing regulated apoptosis in the p53/p73 pathway. Several horchatas have antioxidant and anti-genotoxic capacity that could contribute to the protective effect of this beverage. However, deeper studies are needed to discern the possible synergistic or antagonistic interactions between the species used in traditional medicine.

\section{Abbreviations \\ CBMN assay: Cytokinesis-block micronucleus assay; CHO-K1: Chinese hamster ovary; DMSO: Dimethyl sulfoxide; DNA: Desoxyribonucleic acid; DOXO: Doxorrubicin; DPPH: 2,2-diphenyl-1-picrylhydrazyl; EtBr: Ethidium Bromide; FRAP: Ferric ion reducing capacity; $\mathrm{H}_{2}$ DCFDA: 2'-7'-dichlorofluorescin diacetate; $\mathrm{H}_{2} \mathrm{O}_{2}$ : Hydrogen Peroxide; HBSS: Hanks' Balanced Salt solution; $\mathrm{HRCH}$ : horchata; IC 50 : inhibitory concentration 50\%; MMC: Mytomicin C; PBL: Human peripheral blood lymphocytes; PI: Propidium iodide; ROS: Reactive Oxygen Species; RPMI: Roswell Park Memorial Institute 1640 medium; TEAC: Trolox equivalent antioxidant capacity; TPC: Total Phenolic Contents}

\section{Acknowledgments}

Authors acknowledge Natalia Donoso, Sandra Cuenca and Gabriela González for the technical assistance.

\section{Funding}

Authors thank to UTPL (ECUADOR) for grant No. PROYCCSAL1266 for the financial support.

\section{Availability of data and materials}

Data presented in the manuscript are available upon request.

\section{Authors' contributions}

NBM, FT, and JCRB designed the study. NBM, JCRB, AP, AJ, JA, and RME performed the experiments. NBM, FT, RME, and JCRB analyzed and discussed the data. NBM, JCRB, AP, AJ, and JA wrote the manuscript. All authors read and approved the final manuscript.

\section{Ethics approval and consent to participate}

All subjects gave informed written consent to use human blood samples for research purposes. Research approval was received from Comité de Bioética of Universidad San Francisco-Ecuador-Nº 2017089E.

\section{Consent for publication}

Not applicable.

\section{Competing interests}

The authors declare that they have no competing interests.

\section{Publisher's Note}

Springer Nature remains neutral with regard to jurisdictional claims in published maps and institutional affiliations.

\section{Author details}

'Departamento de Ciencias de la Salud, Universidad Técnica Particular de Loja, Loja, Ecuador. ${ }^{2}$ Departamento de Ciencias Biológicas, Universidad Técnica Particular de Loja, Loja, Ecuador. ${ }^{3}$ Departamento de Química y Ciencias Exactas, Universidad Técnica Particular de Loja, Loja, Ecuador. 
Received: 12 June 2017 Accepted: 6 December 2017 Published online: 19 December 2017

\section{References}

1. Fagundes GE, Damiani AP, Borges GD, Teixeira KO, Jesus MM, Daumann F, et al. Effect of green juice and their bioactive compounds on genotoxicity induced by alkylating agents in mice. J Toxicol Environ Health A. 2017:1-11.

2. Rios M, Tinitana F, Jarrín-V P, Donoso N, Romero-Benavides JC. "Horchata" drink in southern Ecuador: medicinal plants and people's wellbeing. J Ethnobiol Ethnomed; 2017;13:18.

3. Esquivel-Chirino C. Inflammatory Environmental, Oxidative Stress in Tumoral Progression. In: Inflamm Environ Oxidative Stress Tumoral Progress; 2013. 187-208.

4. Surh YJ. Anti-tumor promoting potential of selected spice ingredients with antioxidative and anti-inflammatory activities: a short review. Food Chem Toxicol. 2002:40:1091-7.

5. Brennecke P, Allavena P, Laface I, Mantovani A, Bottazzi B. Inflammatory and Innate Immune Cells in Cancer Microenvironment and Progression. In: Rezaei N, editor. Cancer Immunol. A Transl. Med. Context. Berlin, Heidelberg: Springer-Verlag; 2015. 9-28.

6. Udenigwe CC, Ramprasath VR, Aluko RE, Jones PJH. Potential of resveratro in anticancer and anti-inflammatory therapy. Nutr Rev. 2008;66:445-54

7. Mantovani A, Mantovani A, Allavena P, Allavena P, Sica A, Sica A, et al. Cancer-related inflammation. Nature. 2008:454:436-44.

8. López-Marure R, Gutiérrez G, Mendoza C, Ventura JL, Sánchez L, Reyes Maldonado $\mathrm{E}$, et al. Ceramide promotes the death of human cervical tumor cells in the absence of biochemical and morphological markers of apoptosis. Biochem Biophys Res Commun. 2002;293:1028-36.

9. Hayes JD, Chanas SA, Henderson CJ, McMahon M, Sun C, Moffat GJ, et al. The Nrf2 transcription factor contributes both to the basal expression of glutathione S-transferases in mouse liver and to their induction by the chemopreventive synthetic antioxidants, butylated hydroxyanisole and ethoxyquin. Biochem Soc Trans. 2000;28:33-41.

10. Ooi TC, Chan KM, Sharif R. Antioxidant, anti-inflammatory, and genomic stability enhancement effects of zinc I-carnosine: a potential cancer Chemopreventive agent? Nutr Cancer Taylor \& Francis. 2017;69:201-10.

11. Yum H-W, Na H-K, Surh Y-J. Anti-inflammatory effects of docosahexaenoic acid: implications for its cancer chemopreventive potential. Semin Cancer Biol Elsevier Ltd. 2016:40-41:141-59.

12. Bailón-Moscoso N, Romero-Benavides JC, Ostrosky-Wegman P. Development of anticancer drugs based on the hallmarks of tumor cells. Tumour Biol. 2014;35:3981-95.

13. Ulrich CM, Bigler J, Potter JD. Non-steroidal anti-inflammatory drugs for cancer prevention: promise, perils and pharmacogenetics. Nat Rev Cancer. 2006;6:130-40

14. Grivennikov SI, Greten FR, Karin M. Immunity, inflammation, and cancer. Cell Elsevier Inc. 2010;140:883-99.

15. Steele VE, Kelloff GJ. Development of cancer chemopreventive drugs based on mechanistic approaches. Mutat Res. 2005;591:16-23.

16. Kinghorn AD, B-N S, Jang DS, Chang LC, Lee D, J-Q G, et al. Natural inhibitors of carcinogenesis. Planta Med. 2004;70:691-705.

17. Steward WP, Brown K. Cancer chemoprevention: a rapidly evolving field. $\mathrm{Br}$ J Cancer Nat Publ Group. 2013;109:119-27.

18. Tsao A, Kim E, Hong WK. Chemoprevention of cancer. Cancer Res. 2004;54: 150-80.

19. William WN, Heymach JV, Kim ES, Lippman SM. Molecular targets for cancer chemoprevention. Nat Rev Drug Discov. 2009;8:213-25.

20. Martínez-Valdivieso D, Font R, Fernández-Bedmar Z, Merinas-Amo T, Gómez P. Alonso-Moraga Á, et al. Role of zucchini and its distinctive components in the modulation of degenerative processes: genotoxicity, anti-genotoxicity, cytotoxicity and apoptotic effects. Nutrients. 2017:9:1-21.

21. Tukun AB, Shaheen N, Banu CP, Mohiduzzaman M, Islam S, Begum M. Antioxidant capacity and total phenolic contents in hydrophilic extracts of selected Bangladeshi medicinal plants. Asian Pac J Trop Med. 2014;7:S568-73.

22. Cerón CE. Plantas medicinales de los Andes ecuatorianos. Botánica Económica los Andes Cent. 2006:285-93.

23. Schmidt C, Fronza M, Goettert M, Geller F, Luik S, Flores EMM, et al. Biological studies on Brazilian plants used in wound healing. J Ethnopharmacol. 2009;122:523-32.

24. Choi E, Hwang J. Antiinflammatory, analgesic and antioxidant activities of the fruit of Foeniculum Vulgare. Elsevier. 2004;75:557-65.
25. MJ A. Plantas Medicinales : Plantas Med. Del uso Tradic. al criterio científico. Universidad de Costa Rica; 2010;2:15-17.

26. De TL, DA S, Kvist LP, Lecaro JS. Usos medicinales de las plantas. Encicl. las Plantas Útiles del Ecuador; 2008. p. 105-14.

27. Arango Caro S. Guia de plantas medicinales de uso común en Salento, Colombia. J Chem Inf Model. 2013;53:1689-99.

28. Puertas-Mejía MA, Zuleta-Montoya JF, Rivera-Echeverry F. Capacidad antioxidante in vitro de comfrey Ssymphytum officinale L. Rev Cuba Plantas Med. 2012:17:30-6.

29. Chandra S, Rawat DS. Medicinal plants of the family Caryophyllaceae : a review of ethno-medicinal uses and pharmacological properties. Integr. Med. Res. Korea Institute of Oriental Medicine; 2015. 1-9.

30. Sharopov FS, Zhang H, Setzer WN. Composition of geranium (Pelargonium Graveolens) essential oil from Tajikistan. Am J Essent Oils Nat Prod. 2014;2:13-6.

31. Cole J, England $K$, Madalene H, Lorraine K, Langan M, Sandy M, et al. Pelargoniums. An Herb Society of America guide. Rev Herb Soc Am. 2006:44094:1-57.

32. Rakashanda S, Qazi AK, Majeed R, Andrabi SM, Hamid A, Sharma PR, et al. Plant-derived protease inhibitors LC-pi (Lavatera Cashmeriana) inhibit human lung cancer cell proliferation in vitro. Nutr Cancer. 2015;67(1):156-66.

33. Arumugam $P$, Priya NG, Subathra $M$, Ramesh A. Anti-inflammatory activity of four solvent fractions of ethanol extract of Mentha Spicata L. investigated on acute and chronic inflammation induced rats. Environ Toxicol Pharmacol. 2017;26:92-5.

34. Kaithwasa G, Mukherjeea A, Chaurasiab A, Majumdarc D. Antiinflammatory, analgesic and antipyretic activities of Linum Usitatissimum L. (flaxseed / linseed) fixed oil. Indian J Exp Biol. 2011:49:932-8.

35. Bertero D, Mas M, Verdu A, Trillo C. Plantas Andinas y sus Usos Tradicionales. Cienc Hoy en Linea. 2009;19:1-8.

36. Márquez-Floresa Y, Montellano-Rosalesb H, Campos Aldretec M, MeléndezCamargoa M. Anti-inflammatory activity of aqueous and methanolic extracts of Oenothera Rosea L' Hér. Ex Ait in the rat. Rev. Mex. Ciencias Farm. 2009:40:11-6.

37. Manvitha K, Bidya B. Review on pharmacological activity of Cymbopogon Citratus. Int J Herb Med. 2014:1:5-7.

38. Garcés A, Torres E. El Escaramujo. Propiedades y uso terapeutico. Rev Med Natur. 2010:4:44-52.

39. Pushpalatha KN, Ramachandran VS, Arumugasamy K. Evaluation of antiinflammatory activity of the whole plant extracts of Solanum Americanum miller. (Solanaceae) in albino male rats. South Asian. J Biol Sci. 2011;1:16-20.

40. Pereira C, Meireles A. Valuation of global yield, composition, antioxidant activity and cost of manufacturing of extracts from lemon verbena (aloysia triphylla[l'hérit.] Britton) and mango (mangifera indica l.) leaves. J Food Process Eng. 2006;30:150-73.

41. Mandal SC, Mandal V, Das AK. Qualitative phytochemical screening. Essentials Bot Extr. 2015:173-85.

42. Thaipong K, Boonprakob U, Crosby K, Cisneros-Zevallos L, Hawkins Byrne D. Comparison of ABTS, DPPH, FRAP, and ORAC assays for estimating antioxidant activity from guava fruit extracts. J Food Compos Anal. 2006;19:669-75.

43. Cheng Z, Moore J, High-throughput YL. Relative DPPH radical scavenging capacity assay. J Agric Food Chem. 2006:54:7429-36.

44. Bolanos De La Torre AAS, Henderson T, Nigam PS, Owusu-Apenten RK. A universally calibrated microplate ferric reducing antioxidant power (FRAP) assay for foods and applications to Manuka honey. Food Chem Elsevier Ltd. 2015;174:119-23.

45. Srinivas G, Anto RJ, Srinivas P, Vidhyalakshmi S, Senan VP, Karunagaran D. Emodin induces apoptosis of human cervical cancer cells through poly(ADP-ribose) polymerase cleavage and activation of caspase-9. Eur J Pharmacol. 2003;473:117-25

46. Bailon-Moscoso N, González-Arévalo G, Velásquez-Rojas G, Malagon O, Vidar G, Zentella-Dehesa A, et al. Phytometabolite Dehydroleucodine induces cell cycle arrest, apoptosis, and DNA damage in human astrocytoma cells through p73/p53 regulation. PLoS one. Public Libr Sci. 2015;10:e0136527.

47. Hempel SL, Buettner GR, O'Malley YQ, Wessels DA, Flaherty DM. Dihydrofluorescein diacetate is superior for detecting intracellular oxidants: comparison with 2',7'-dichlorodihydrofluorescein diacetate, 5(and 6)carboxy-2',7'-dichlorodihydrofluorescein diacetate, and dihydrorhodamine 123. Free Radic Biol Med. 1999:27:146-59.

48. Bailon-Moscoso N, Romero-Benavides JC, Orellana Ramirez MI, Ojeda K, Granda G, Ratovitski E, et al. Cytotoxic and genotoxic effects of extracts from Annona Montana M. Fruit. Food Agric Immunol. 2016;27:559-69.

49. Slowinski J, Bierzynska-Macyszyn G, Mazurek U, Widel M, Latocha M, Stomal $\mathrm{M}$, et al. Cytokinesis-block micronucleus assay in human glioma cells exposed to radiation. Image Anal Stereol. 2004;23:159-65. 
50. Fenech M. Cytokinesis-block micronucleus cytome assay. Nat Protoc. 2007:2:1084-104.

51. Chipuk JE, Green DR. Dissecting p53-dependent apoptosis. Cell Death Differ. 2006;13:994-1002.

52. Cam H, Griesmann H, Beitzinger M, Hofmann L, Beinoraviciute-Kellner R, Sauer M, et al. P53 family members in myogenic differentiation and rhabdomyosarcoma development. Cancer Cell. 2006;10:281-93.

53. Pietsch EC, Sykes SM, McMahon SB, Murphy ME. The p53 family and programmed cell death. Oncogene. 2008;27:6507-21.

54. Smeenk L, van Heeringen SJ, Koeppel M, Gilbert B, Janssen-Megens E, Stunnenberg $\mathrm{HG}$, et al. Role of p53 serine 46 in p53 target gene regulation. PLoS One. 2011;6

55. Kim YJ, Son DY. Antioxidant effects of solvent extracts from the dried jujube (Zizyphus jujube) sarcocarp, seed, and leaf via sonication. Food Sci Biotechnol. 2011;20:167-73.

56. Wang R, Liu YY, Liu XY, Jia SW, Zhao J, Cui D, et al. Resveratrol protects neurons and the myocardium by reducing oxidative stress and ameliorating mitochondria damage in a cerebral ischemia rat model. Cell Physiol Biochem. 2014;34:854-64.

57. Azam S, Hadi N, Khan NU, Hadi SM. Prooxidant property of green tea polyphenols epicatechin and epigallocatechin-3-gallate : implications for anticancer properties. Toxicol Vitr. 2004;18:555-61.

58. Kavvadias D, Sand P, Youdim KA, Qaiser MZ, Rice-Evans C, Baur R, et al. The flavone hispidulin, a benzodiazepine receptor ligand with positive allosteric properties, traverses the blood-brain barrier and exhibits anticonvulsive effects. Br J Pharmacol. 2004;142:811-20.

59. Rigas B, Sun Y. Induction of oxidative stress as a mechanism of action of chemopreventive agents against cancer. Br J Cancer. 2008:98:1157-60

60. Ramos S. Cancer chemoprevention and chemotherapy: dietary polyphenols and signalling pathways. Mol Nutr Food Res. 2008:507-26.

61. Lenzi M, Malaguti M, Cocchi V, Hrelia S, Hrelia. castanea Sativa mill. Bark extract exhibits chemopreventive properties triggering extrinsic apoptotic pathway in Jurkat cells. BMC complement. Altern Med BMC Complement Altern Med. 2017;17:251.

62. Chaouki W, Leger DY, Liagre B, Beneytout JL, Hmamouchi M. Citral inhibits cell proliferation and induces apoptosis and cell cycle arrest in MCF-7 cells. Fundam Clin Pharmacol. 2009;23:549-56.

63. Zu Y, Yu H, Liang L, Fu Y, Efferth T, Liu X, et al. Activities of ten essential oils towards Propionibacterium acnes and PC-3, A-549 and MCF-7 cancer cells. Molecules. 2010;15:3200-10.

64. Sharma V, Hussain S, Gupta M. In vitro anticancer activity of extracts of Mentha Spp. against human cancer cells. Indian J Biochem Biophys. 2014;51:416-9.

65. Berdowska I, Zieliński B, Fecka I, Kulbacka J, Saczko J, Gamian A. Cytotoxic impact of phenolics from Lamiaceae species on human breast cancer cells. Food Chem. 2013;141:1313-21.

66. Liou G-Y, Storz P. Reactive oxygen species in cancer. Free Radic Res. 2010; 44:479-96.

67. Meschini R, Berni A, Filippi S, Pepe G, Grossi MR, Natarajan AT, et al. The micronucleus assay in mammalian cells in vitro to assess health benefits of various phytochemicals. Mutat. Res. - genet. Toxicol. Environ. Mutagen. Elsevier Ltd. 2015;793:79-85.

68. Roberto MM, Matsumoto ST, Jamal CM, Malaspina O, Marin-Morales MA. Evaluation of the genotoxicity/mutagenicity and antigenotoxicity/ antimutagenicity induced by propolis and Baccharis dracunculifolia, by in vitro study with HTC cells. Toxicol Vitr Elsevier Ltd. 2016;33:9-15.

69. Jacociunas LV, De Andrade HHR, Lehmann M, Pedersini LW, Ferraz ADBF, Da Silva J, et al. Protective activity of Cynara Scolymus L. leaf extract against chemically induced complex genomic alterations in $\mathrm{CHO}$ cells. Phytomedicine Elsevier GmbH. 2013;20:1131-4. A

70. Charehsaz M, Sipahi H, Giri AK, Aydin A. Antimutagenic and anticlastogenic effects of Turkish black tea on TA98 and TA100 strains of salmonella typhimurium (in vitro) and mice (in vivo). Pharm Biol. 2017;55:1202-6.

71. Hanahan D, Weinberg RA. Hallmarks of cancer: the next generation. Cell Elsevier Inc. 2011;144:646-74.

72. Fiaschi T, Chiarugi P. Oxidative stress, tumor microenvironment, and metabolic reprogramming: a diabolic liaison. Int. J Cell Biol. 2012;2012:762825.

73. Colotta F, Allavena P, Sica A, Garlanda C, Mantovani A. Cancer-related inflammation, the seventh hallmark of cancer: links to genetic instability. Carcinogenesis. 2009;30:1073-81.

\section{Submit your next manuscript to BioMed Central and we will help you at every step:}

- We accept pre-submission inquiries

- Our selector tool helps you to find the most relevant journal

- We provide round the clock customer support

- Convenient online submission

- Thorough peer review

- Inclusion in PubMed and all major indexing services

- Maximum visibility for your research

Submit your manuscript at www.biomedcentral.com/submit
Biomed Central 